九州大学学術情報リポジトリ

Kyushu University Institutional Repository

\title{
A Strain Pediococcus sp. ISK-1 Isolated from Nukadoko Produces a Novel Bacteriocin
}

Kimura, Hi rokazu

Laboratory of Microbial Technology, Department of Food Science and Technology, Faculty of Agriculture, Kyushu University

Nagano, Rie

Laboratory of Microbial Technology, Department of Food Science and Technology, Faculty of Agriculture, Kyushu University

Matsusaki, Hiromi

Laboratory of Microbial Technology, Department of Food Science and Technology, Faculty of Agriculture, Kyushu University

Sonomoto, Kenji

Laboratory of Microbial Technology, Department of Food Science and Technology, Faculty of Agriculture, Kyushu University

他

https://doi.org/10.5109/24199

出版情報：九州大学大学院農学研究院紀要. 42 (1/2)，pp.121-129，1997-12. Kyushu University バージョン：

権利関係 : 


\title{
A Strain Pediococcus sp. ISK-1 Isolated from Nukadoko Produces a Novel Bacteriocin
}

\author{
Hirokazu Kimura, Rie Nagano, Hiromi Matsusaki, \\ Kenji Sonomoto and Ayaaki Ishizaki
}

\author{
Laboratory of Microbial Technology, Department of Food Science and Technology, Faculty of \\ Agriculture, Kyushu University, 6-10-1 Hakozaki, Higashi-ku, Fukuoka 812-81, Japan \\ (Received June 16, 1997 and accepted August 25, 1997)
}

\begin{abstract}
Pediococcus sp. ISK-1 isolated in our laboratory from well-aged Nukadoko, produces a bacteriocin which has a unique antimicrobial spectrum among pediocins. The antimicrobial activity was detected at the late exponential growth phase during fermentation and reached the maximum at the late stationary phase. The bacteriocin was stable at acidic $\mathrm{pH}$, and more than $60 \%$ of the antimicrobial activity still remained even after being autoclaved at $121^{\circ} \mathrm{C}$ for $20 \mathrm{~min}$ in the $\mathrm{pH}$ range of 3 to 8 . This is the first report dealt with bacteriocin produced by lactic acid bacteria isolated from Nukadoko.
\end{abstract}

\section{INTRODUCTION}

Many lactic acid bacteria are industrially important microorganisms, and they are used in traditional fermented foods. Some lactic acid bacteria produce several antimicrobial substances including organic acids, hydrogen peroxide, and bacteriocins which are responsible for antagonistic activity. It is reasonable that these antimicrobial substances may contribute to the storage of fermented foods and the stabilization of the microflora. The preservative effect of lactic acid bacteria has been investigated to enhance the quality of foods. Bacteriocins from lactic acid bacteria are proteinaceous compounds which generally exhibit bactericidal mode of action against Gram-positive bacteria that are closely related to bacteriocin-producing species (Tagg et al., 1976). Among bacteriocins produced by lactic acid bacteria, nisin and pediocin have been genetically and biochemically well-investigated (Klaenhammer, 1993). Nisin has been approved by the World Health Organization as a preservative in the food industry. Recently, we have succeeded in purification of bacteriocin from the culture broth of Lactococcus lactis IO-1 (JCM7638) isolated in our laboratory (Matsusaki et al., 1996a). The bacteriocin was identical with nisin $\mathrm{Z}$, a natural nisin variant. Furthermore, we have successfully achieved nisin $\mathrm{Z}$ fermentative production, resulting in about three-fold yield of the peptide (Matsusaki et al., 1996b).

Pediocin is produced by Pediococcus sp. which are widely associated with the fermentation of meat and vegetables. The two principal species, $P$. acidilactici and $P$. pentosaceus, have been found to produce bacteriocins, e. g. pediocin AcH (Bhunia et al., 1988), pediocin PA-1 (Henderson et al., 1992), pediocin SJ-1 (Schved et al., 1993), and pediocin L50 (Cintas et al., 1995) which were purified from fresh and fermented sausage. These bacteriocins have molecular mass of 2,700 to 4,600 $\mathrm{Da}$ and are sensitive to proteolytic enzymes. Pediocin is resistant to heat and some organic solvent and is active 
over a wide range of $\mathrm{pH}$. The antimicrobial activity of pediocin occurs through changes in the membrane potentials of indicator microorganisms, which leads to a collapse of proton motive force, an efflux of intracellular ions and cell death (Bhunia et al., 1991; Christensen and Hutkins, 1992; Chikindas et al., 1993; Chen and Montville, 1995). The wide antimicrobial spectrum against food-borne pathogens and spoilage microorganisms such as iisteria and clostridia enables pediocin to be used as a natural food biopreservative (Pucci et al., 1988; Nielsen et al., 1990; Foegeding et al., 1992).

A quite unique new strain, Pediococcus sp. ISK-1 was isolated in our laboratory from well-aged Nukadoko, the bed of fermented rice bran where exist not only yeast but a variety of Gram-positive bacteria. Salt-tolerant bacteria such as Lactobacillus and Pediococcus are known to be associated with Nukadoko. A homofermentative lactic acid bacterium, strain ISK-1 utilize xylose as well as glucose as carbon source but not lactate. Moreover, this strain was proved to grow well under $18 \% \mathrm{NaCl}$ (Ishizaki et al., unpublished results). It is reasonable to assume that some of the lactic acid bacteria associated with Nukadoko might be able to produce bacteriocins which maintain the quality of Nukadoko for a long time. However, few results are available in the literature for bacteriocins produced by salt-tolerant lactic acid bacteria from Nukadoko. This paper deals with partial characterization of the bacteriocin from strain ISK-1. The results showed that this bacteriocin, designated ISK-1 bacteriocin, was probably a novel pediocin compared to the others reported to date.

\section{MATERIALS AND METHODS}

\section{Strains and culture condition}

Pediococcus sp. ISK-1, a new strain isolated in our laboratory from well-aged fermented Nukadoko, was used in this study. Bacillus subtilis C1 (Ishizaki et al., 1992a), which was also isolated in our laboratory, was used as indicator microorganism for assays of antimicrobial activity. B. subtilis $\mathrm{C} 1$ was aerobically cultivated at $30^{\circ} \mathrm{C}$ for $18 \mathrm{~h}$ in bouillon liquid medium containing $0.7 \%$ meat extract, $1.0 \%$ polypeptone and $0.5 \%$ $\mathrm{NaCl}$. For the production of ISK-1 bacteriocin, the stock culture of Pediococcus sp. ISK1 was statically subcultured in $10 \mathrm{ml}$ of thioglycolate medium without glucose (TGC medium; Difco Laboratories, USA) at $37^{\circ} \mathrm{C}$ for $18 \mathrm{~h}$ and then transferred to $100 \mathrm{ml}$ of the following medium, referred to as. CMG medium. CMG medium contained $1.0 \%$ glucose, $0.5 \%$ yeast extract, $0.5 \%$ polypeptone and $0.5 \% \mathrm{NaCl}$ in distilled water at $\mathrm{pH} 7.0$ for preculture. An aliquot of $25 \mathrm{ml}$ of the preculture, after growth at $37^{\circ} \mathrm{C}$ for $6 \mathrm{~h}$, was inoculated into a 1-liter jar fermentor with a working volume of $500 \mathrm{ml}$ of CMG medium. The fermentation was carried out at $\mathrm{pH} 6.0$, maintained by a feeding system that supplied $3 \mathrm{~N} \mathrm{NaOH}$, at $37^{\circ} \mathrm{C}$ with agitation speed of $440 \mathrm{rpm}$ without aeration.

\section{Analytical condition}

Cell density was monitored by absorbance at $562 \mathrm{~nm}$ and converted to dry cell weight from a standard curve. Glucose concentrations was analyzed according to the method described previously (Ishizaki et al., 1992b), and lactate concentration was determined by the high performance liquid chromatography (638-30 HPLC., Hitachi Co. Ltd., Japan) with a spectrophotometric detector (SPD-10AV, Shimazu Co. Ltd., Japan) at $210 \mathrm{~nm}$. The 
analytical conditions were as follows: column, Aminex HPX- $87 \mathrm{H}(0.78 \times 30 \mathrm{~cm}, \mathrm{Bio}-\mathrm{Rad}$ Co. Ltd., USA); column temperature, $65^{\circ} \mathrm{C}$; solvent for elution, $50 \mathrm{mM} \mathrm{H}_{2} \mathrm{SO}_{4}$ solution; flow rate, $0.2 \mathrm{ml} / \mathrm{min}$ (Masson et al., 1991).

\section{Bacteriocin preparation}

The culture supernatant of Pediococcus sp. ISK-1 from a jar fermentor was adjusted to $\mathrm{pH} 3.0$ with concentrated $\mathrm{HCl}$ and was allowed to stand overnight at $4{ }^{\circ} \mathrm{C}$. After the precipitate formed was removed by centrifugation at $16,000 \times \mathrm{g}$ for $20 \mathrm{~min}$, the active supernatant was brought to $90 \%$ saturation by the addition of solid ammonium sulphate and allowed to stand overnight at $4{ }^{\circ} \mathrm{C}$. The precipitate was collected by centrifugation at $16,000 \times \mathrm{g}$ for $20 \mathrm{~min}$ and then suspended in a small volume of $0.01 \mathrm{~N} \mathrm{HCl}$. This suspension was dialyzed against $20 \mathrm{mM}$ Tris-HCl buffer $(\mathrm{pH} 7.6)$ in a Spectra/Por membrane (Spectrum Medical Industries, Inc., USA; molecular weight cut off, 1,000). Twenty $\mathrm{ml}$ of the active dialyzate was obtained. Unless otherwise noted, the concentrated and desalted ISK-1 bacteriocin sample was used to investigate the characterization.

\section{Bioassay}

The antimicrobial activity was detected by the two bioassay methods using turbidimetric assay and agar disc diffusion assay. The turbidimetric assay was performed in test tubes containing $5 \mathrm{ml}$ of the assay medium (10-fold diluted CMG medium) buffered with $20 \mathrm{mM}$ sodium phosphate buffer ( $\mathrm{pH} 7.0$ ). Fifty microliter of 100-fold diluted culture of $B$. subtilis $\mathrm{Cl}$ grown for $18 \mathrm{~h}$ at $30^{\circ} \mathrm{C}$ with shaking (120 strokes/min) was inoculated into each test tube, and then an appropriate volume of the ISK-1 bacteriocin sample was added aseptically. The test tubes containing assay mixture were incubated at $30^{\circ} \mathrm{C}$ for 18 h. The absorbance at $562 \mathrm{~nm}$ of the assay medium was measured to confirm the growth inhibition of the indicator strain B. subtilis C1.

Agar disc diffusion assay was performed as follows. One hundred microliters of $100-$ fold diluted indicator culture grown for $18 \mathrm{~h}$ was seeded in $10 \mathrm{ml}$ of MRS (Oxoid, England) or bouillon soft agar media ( $0.7 \%$ agar). The mixture was poured into petridishes. After solidification of the soft agar media, sterile paper discs $(10 \mathrm{~mm}$ diameter) with the original or a serial 2 -fold diluted sample of ISK-1 bacteriocin were placed on the surface. After the plates were incubated for $18 \mathrm{~h}$ at the optimum temperature for each indicator microorganism, inhibitory zones formed around the paper discs were observed.

For the turbidimetric assay, the antimicrobial activity was defined as a nisin converting unit (NCU) in which $1 \mathrm{NCU}$ is equivalent to the activity of $1 \mathrm{~g}$ of commercial nisin (ICN Biomedicals Inc., USA; activity, 1,000 U/mg-solid).

\section{pH and heat stability of ISK-1 bacteriocin}

ISK-1 bacteriocin sample was exposed to various pHs at $4{ }^{\circ} \mathrm{C}$ or $30^{\circ} \mathrm{C}$ for $24 \mathrm{~h}$. The bacteriocin was also autoculaved at $121^{\circ} \mathrm{C}$ for $20 \mathrm{~min}$. The each sample was adjusted to $\mathrm{pH} 3.0$ with $\mathrm{HCl}$ or $\mathrm{NaOH}$ after the treatments, and then the antimicrobial activity was determined by a turbidimetric assay.

\section{Effects of enzyme treatment on antimicrobial activity}


The enzymes, acid protease (Sigma, USA), trypsin (Sigma), $\alpha$-chymotrypsin (Sigma), proteinase K (Merck, Germany), pepsin (Nacalai Tesque, Japan), ficin (Sigma), papain (Merck), Actinase E (Kaken Seiyaku, Japan), pancreatin (Nacalai Tesque), lysozyme (Seikagaku Kogyo, Japan), lipase (Sigma), ribonuclease A (Sigma) and $\alpha$-amylase (Katayama Kagaku, Japan) were dissolved at a concentration of $2 \mathrm{mg} / \mathrm{ml}$ in the following buffer; acid protease and pepsin in $70 \mathrm{mM}$ Sørensen buffer (disodium hydrogen citrate$\mathrm{HCl}$ ) at $\mathrm{pH} 2.0$ and $\mathrm{pH} 2.8$, respectively, papain and lysozyme in $70 \mathrm{mM}$ phosphate buffer at $\mathrm{pH} 6.0$, trypsin, $\alpha$-chymotrypsin, proteinase $\mathrm{K}$, actinase $\mathrm{E}$, ficin, pancreatin, lipase, ribonuclease $\mathrm{A}$ and $\alpha$-amylase in $70 \mathrm{mM}$ phosphate buffer at $\mathrm{pH} 7.0$. Two milliliters of ISK-1 bacteriocin sample were loaded on a $\mathrm{tC}_{18}$ Sep-Pak cartridge (Waters, USA), and the column was washed with $0.05 \%$ trifluoroacetic acid (TFA). The fraction with antimicrobial activity was eluted with $50 \%$ acetonitrile in $0.05 \%$ TFA. The eluate was lyophilized and then the active material was dissolved in $1 \mathrm{ml}$ of each buffer. The bacteriocin sample was added to $1 \mathrm{ml}$ of each enzyme reaction solution, and the reaction mixture was incubated for $24 \mathrm{~h}$ at the indicated temperature of each enzyme. The each antimicrobial activity was then determined by a turbidimetric assay. Reaction mixtures without enzymes were used as positive controls.

\section{Antimicrobial spectrum of ISK-1 bacteriocin}

An agar disc diffusion assay was used to investigate the antimicrobial spectrum of the bacteriocin produced by strain ISK-1. The microorganisms tested were $P$. acidilactici JCM 5885",$B$. subtilis C1 (Ishizaki et al., 1992a), P. pentosaceus JCM 5809 ${ }^{\mathrm{T}}$,

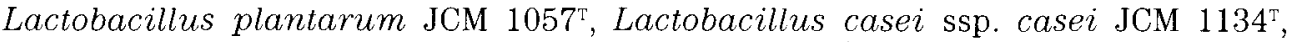
Lactococcus lactis IO-1 (nisin Z producing-strain isolated in our laboratory (Matsusaki et al., 1995) ), Lactococcus lactis JCM 5805 ${ }^{\mathrm{T}}$, Lactococcus lactis ssp. cremoris TUA 13442 and $M$. luteus IFO 12708. MRS, LB and bouillon agar plate media were used for lactic acid bacteria, $M$. luteus and $B$. subtilis, respectively. The each plate was incubated for $18 \mathrm{~h}$ at the optimum temperature of the microorganism tested.

\section{RESULTS}

\section{ISK-1 bacteriocin production}

As a result of preliminary work, a peptide antibiotic was partially purified from Nukadoko by ammonium sulphate precipitation, two times gel filtration chromatography with a Sephadex G-50 and reverse-phase chromatography (data not shown).

Relationship between the growth and the bacteriocin production of strain ISK-1 was investigated in CMG medium. The antimicrobial activity of the culture supernatant was determined by a turbidimetric assay after it was desalted by Micro Acylizer G1 (Asahikasei Co. Ltd., Japan) to remove the inhibitory effect of organic acids. As shown in Fig. 1, the antimicrobial activity of the culture supernatant was detected at the late exponential phase of growth, and a maximum level of $0.232 \mathrm{NCU} / l$ was obtained at the end of the stationary phase of growth.

\section{pH and heat stability of ISK-1 bacteriocin}

$\mathrm{pH}$ and heat stability of ISK-1 bacteriocin was examined by a turbidimetric assay. As 
shown in Fig. 2, in spite of instability at $30^{\circ} \mathrm{C}$, the storage at $4{ }^{\circ} \mathrm{C}$ for $24 \mathrm{~h}$ resulted in a good stability in the $\mathrm{pH}$ range of 2 to 12 . At $121^{\circ} \mathrm{C}$, more than $60 \%$ of the antimicrobial activity still retained in the $\mathrm{pH}$ range of 3 to 8 . This indicates that the bacteriocin is heat stable.

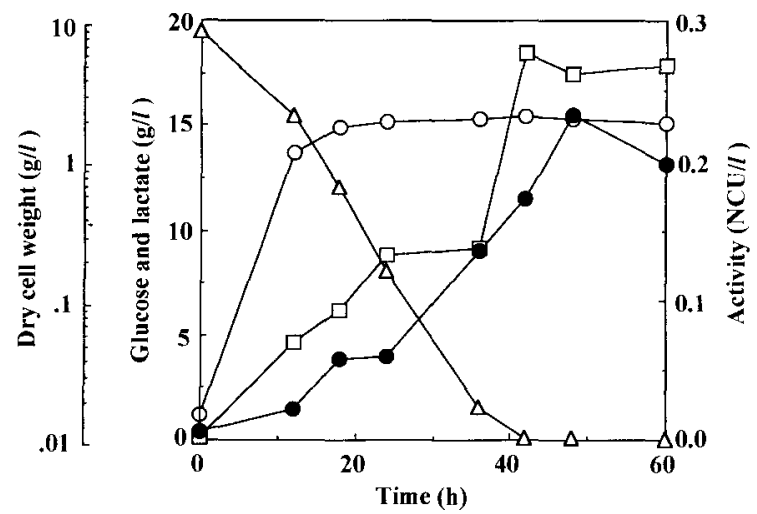

Fig. 1. Batch Fermentation Profile of Pediococcus sp. ISK-1.

The $\mathrm{pH}$-controlled fermentation was carried out as described in Materials and Methods.

cell growth $(\bigcirc)$, residual glucose concentration $(\triangle)$, lactate production $(\square)$ and activity of bacteriocin $(\mathbf{O})$.

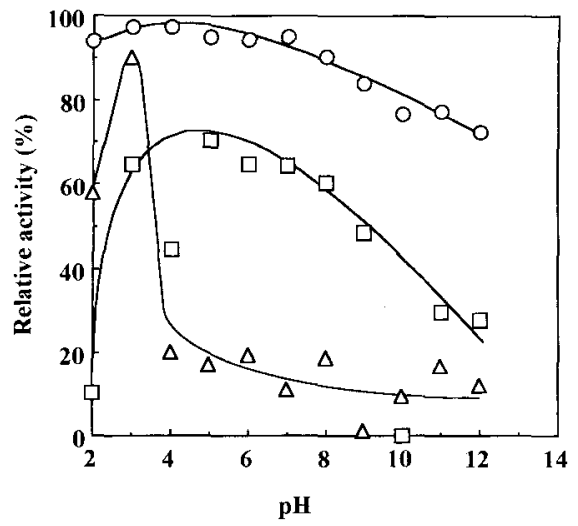

Fig. 2. pH and Heat Stability of the Bacteriocin Produced by Pediococcus sp. ISK-1.

Symbols: stored at $4^{\circ} \mathrm{C}$ for $24 \mathrm{~h}(\bigcirc)$; stored at $30^{\circ} \mathrm{C}$ for $24 \mathrm{~h}(\triangle)$; autoclaved at $121^{\circ} \mathrm{C}$ for $20 \mathrm{~min}(\square)$. The fresh ISK-1 bacteriocin sample having the activity of $0.199 \mathrm{NCU} / l$ was defined as $100 \%$. 


\section{Effects of enzyme treatment on the antimicrobial activity}

The effects of enzyme treatment on the antimicrobial activity of ISK-1 bacteriocin were examined by a turbidimetric assay. The bacteriocin was inactivated by acid protease, $\alpha$-chymotrypsin, pepsin, ficin and papain, while it was not affected by lysozyme, lipase, ribonuclease A and $\alpha$-amylase (Table 1). This suggests that the antimicrobial substance produced by Pediococcus sp. ISK-1 could be a proteinaceous inhibitory substance, that is a bacteriocin (Tagg et al., 1976).

Table 1. Effects of Enzyme Treatment on the Antimicrobial Activity of the Bacteriocin Produced by Pediococcus sp. ISK-1

\begin{tabular}{llcc}
\hline Enzyme & Maker & Activity & Reaction temperature ( $\left.{ }^{\circ} \mathrm{C}\right)$ \\
\hline \multirow{2}{*}{ Acid protease } & Sigma, USA & - & 37 \\
Trypsin & Sigma & + & 25 \\
$\alpha$-Chymotrypsin & Sigma & - & 25 \\
Proteinase K & Merck, Germany & + & 37 \\
Pepsin & Nakalai Tesque, Japan & - & 37 \\
Ficin & Sigma & - & 37 \\
Papain & Merck & - & 40 \\
Actinase E & Kaken Seiyaku, Japan & - & 40 \\
Pancreatin & Nakalai Tesque & - & 37 \\
Lysozyme & Seikagaku Kogyo, Japan & + & 35 \\
Lipase & Sigma & + & 37 \\
Ribonuclease A & Sigma & + & 37 \\
$\alpha$-Amylase & Katayama Kagaku, Japan & + & 37 \\
\hline
\end{tabular}

ISK-1 bacteriocin was partially purified as described in Materials and Methods and then used in this experiment.

"Antimicrobial activity was determined by a turbidimetric assay. ( + , presence and - , loss of activity)

\section{Antimicrobial spectrum of ISK-1 bacteriocin}

A more sensitive indicator microorganism to ISK-1 bacteriocin should be used for the purification and the investigation of the characterization. P. acidilactici JCM $5885^{\mathrm{T}}$ was the most sensitive to ISK-1 bacteriocin among the microorganisms tested in this study (Table 2). It was found that ISK-1 bacteriocin inhibited the growths of neither Lactobacillus plantarum nor P. pentosaceus, although established pediocins inhibited growth of them (Bhunia et al., 1988; Henderson et al., 1992; Schved et al., 1993; Cintas et al., 1995). The clear inhibitory zone of ISK-1 bacteriocin against $P$. acidilactici JCM $5885^{\mathrm{T}}$ and M. luteus IFO 12708 are shown in Fig. 3. 
Table 2. Antimicrobial Spectrum of the Bacteriocin from Pediococcus sp. ISK-1

\begin{tabular}{ll}
\hline Indicator organisms & Inhibition \\
\hline Pediococcus acidilactici JCM 5885 & +++ \\
Pediococcus pentosaceus JCM 5809 & - \\
Lactobacillus plantarum JCM $1057^{\mathrm{T}}$ & - \\
Lactobacillus casei ssp. casei JCM 1134 & ++ \\
Lactococcus lactis IO-1 & - \\
Lactococcus lactis JCM 5805 & ++ \\
Lactococcus lactis SSp. cremoris TUA 13442 & - \\
Micrococcus luteus IFO 12708 & ++ \\
Bacillus subtilis C1 & + \\
\hline
\end{tabular}

ISK-1 bacteriocin sample used here was dialyzed as described in the text.

"Nisin Z-producing strain isolated in our laboratory (Matsusaki $e t$ al., 1996a).

+++ : Large inhibitory zone $(>20 \mathrm{~mm})$

++ : Medium inhibitory zone $(15-20 \mathrm{~mm})$

+ : Small inhibitory zone (10-15 mm)

- : No inhibitory zone

JCM: Japan Collection of Microorganisms

IFO: Institute for Fermentation, Osaka, Japan.

TUA: Tokyo University of Agriculture, Japan.
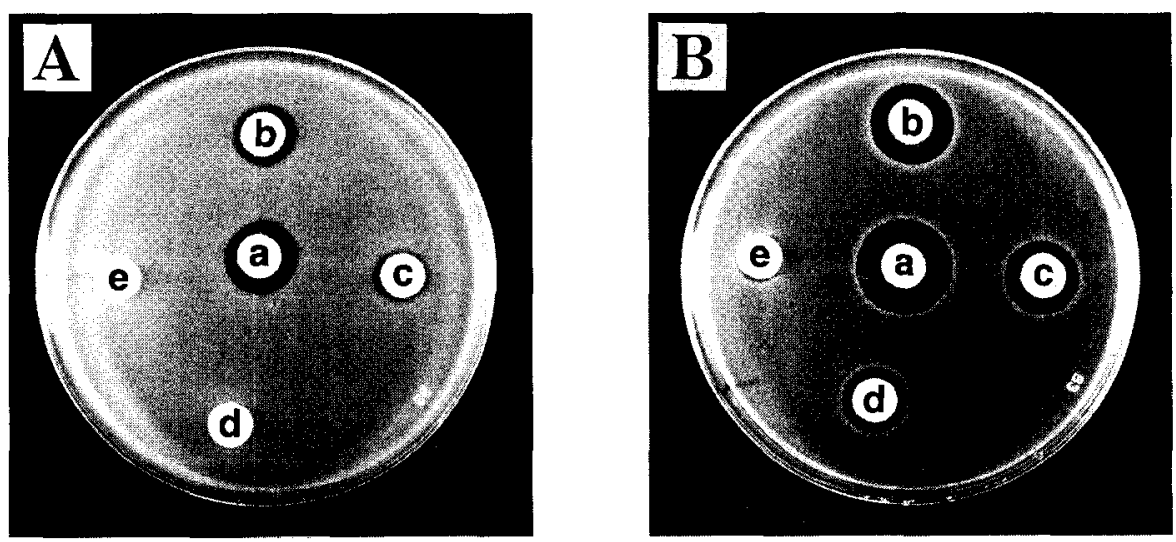

Fig. 3. Inhibitory Zones of Bacteriocin of Pediococcus sp. ISK-1 against Micrococcus luteus IFO 12708 (A) and Pediococcus acidilactici JCM 5885 (B).

Discs contained $40 \mu \mathrm{l}$ of each sample. (a), original; (b), 2 -fold diluted; (c), 4-fold diluted; (d), 8-fold diluted; (e), 16-fold diluted

\section{DISCUSSION}

Nukadoko, well-aged and kept over several hundred year is attractive as a source for unique lactic acid bacteria differing in characteristics such as carbohydrate utilization and bacteriocin production. The formation of some kinds of bacteriocin as well as acidic end- 
products, primarily lactic acid, from the fermentation of carbohydrate-rich substrates such as rice bran is largely responsible for creating an environment unfavorable for the growth of spoilage organisms. Little work has been done to find out bacteriocinproducing lactic acid bacteria from Nukadoko. In this paper, we clarified the isolate, Pediococcus sp. ISK-1 to produce a bacteriocin and also characterized it.

The bacteriocin of strain ISK-1 which was dialyzed after ammonium sulphate precipitation as described in Materials and Methods, was unstable at $30^{\circ} \mathrm{C}$ (Fig. 2) since a lot of extracellular proteases might be secreted and present in the bacteriocin sample. This should be predictable from the result that the partially purified bacteriocin was stable at $35-37^{\circ} \mathrm{C}$ for $24 \mathrm{~h}$ without many kinds of protease (Table 1). Furthermore, autoclave treatment of the dialyzed bacteriocin resulted in not only a good stability of the peptide but a denaturation of the protease contaminants. Heat stability of ISK-1 bacteriocin over a wide range of $\mathrm{pH}$ is the characteristic of pediocin produced by some strains of Pediococcus sp (Klaenhammer, 1993). Nisin is used as a food preservative in many countries (Delves-Broughton, 1990). However, the application in foods is limited because of the $\mathrm{pH}$ stability. Therefore, ISK-1 bacteriocin may be preferable for the commercial application.

Moreover, the antimicrobial spectrum of ISK-1 bacteriocin suggests that it might be different from pediocins published to date. To ensure whether it is a novel pediocin or not, it is necessary to purify the bacteriocin of strain ISK-1 and to characterize it in detail.

The genetic determinants for both pediocin production and immunity are linked to plasmid DNA (Klaenhammer, 1993). It was found that strain ISK-1 possessed at least two plasmids (53 $\mathrm{kbp}$ and $2 \mathrm{kbp}$ ) and these plasmids were designated pPI1 and pPI2, respectively (data not shown). No deletion of antimicrobial activity occurred through curing plasmid pPI2 by growth at elevated temperature. Thus plasmid pPI2 was not linked to the bacteriocin production. It has not been proved whether plasmid pPI1 is linked to the bacteriocin production or not. At least, the plasmid sizes of strain ISK-1 were quite different from those of pediocin-producing strains (Bhunia et al., 1988; Henderson et al., 1992; Schved et al., 1993; Cintas et al., 1995).

\section{REFERENCES}

Bhunia, A. K., Johnson, M. C. and B. Ray 1988 Purification, characterization and antimicrobial spectrum of a bacteriocin produced by Pediococcus acidilactici. J. Appl. Bacteriol, 65: 261-268

Bhunia, A. K., Johnson, M. C., Ray, B. and N. Kalchayanand 1991 Mode of action of pediocin AcH from Pediococcus acidilactici $\mathrm{H}$ on sensitive bacterial strains. J. Appl. Bacteriol, 70: 25-33

Chen, Y. and T. J. Montville 1995 Efflux of ions and ATP deletion induced by pediocin PA-1 are concomitant with cell death in Listeria monocytogenes Scott A. J. Appl. Bacteriol., 79: 684-690

Chikindas, M. L., Garcia-Garcera, M. J., Driessen, A. J. M., Ledeboer, A. M., Nissen-Meyer, J., Nes, I. N., Abee, T., Konings, W. N. and G. Venema 1993 Pediocin PA-1, a bacteriocin from Pediococus acidilactici PAC1.0, forms hydrophilic pores in the cytoplasmic membrane of target cells. Appl. Environ. Microbiol., 59: 3577-3584

Christensen, D. P. and R. W. Hutkins 1992 Collapse of the proton motive force in Listeria monocytogenes caused by a bacteriocin produced by Pediococcus acidilactici. Appl. Environ. Microbiol., 58: $3312-3315$

Cintas, L. M., Rodriguez, J. M., Fernandez, M. F., Sletten, K., Nes, I. F., Hernandez, P. E., and H. Holo 1995 Isolation and characterization of pediocin L50, a new bacteriocin from Pediococcus acidilactici with a broad inhibitory spectrum. Appl. Envirom. Microbiol., 61: 2643-2648 
Delves-Broughton, J. 1990 Nisin and its use as a food preservatives. Food Technol., 44: 100-117

Foegeding, P. M., Thomas, A. B., Pilkington, D. H. and T. R. Klaenhammer 1992 Enhanced control of Listeria monocytogenes by in situ-produced pediocin during dry fermented sausage production. Appl. Environ. Microbiol., 58: 884-890

Henderson, J. T., Chopko, A. L. and P. D. van Wassenaar 1992 Purification and primary structure of pediocin PA-1 produced by Pediococcus acidilactici PAC-1.0. Arch. Biochem. Biophys., 295: 5-12

Hurst, A. 1981 Nisin. Adv. Appl. Microbiol., 27: 85-123

Ishizaki, A., Tamura, M., Kimura, K., Koba, Y. and M. Tonokawa 1992a Characterization of newly isolated Bacillus subtilis $\mathrm{C} 1$ which is sensitive to antibiotic produced by lactic acid coccus. J. Ferment. Bioeng., 74: $248-250$

Ishizaki, A., Ueda, T., Tanaka, K. and P. F. Stanbury 1992b L-Lactate production from xylose employing Lactococcus lactis IO-1. Biotechnol. Lett., 14: 599-604

Klaenhammer, T. R. 1993 Genetics of bacteriocins produced by lactic acid bacteria. FEMS Microbiol. Rev., 12: 39-86

Matsusaki, H., Endo, N., Sonomoto, K. and A. Ishizaki 1996a Development of purification method and identification of a peptide antibiotic produced by Lactococcus lactis IO-1. Food Sci. Technol., Int., 2: 157-162

Matsusaki, H., Endo, N., Sonomoto, K. and A. Ishizaki 1996b Lantibiotic nisin Z fermentative production by Lactococcus lactis IO-1: Relationship among production of the lantibiotic and lactate and cell growth. Appl. Microbiol. Biotechnol., 45: $36-40$

Masson, S., Sciaky, M., Desmoulin, F., Fontanarava, E., and P. J. Cozzone 1991 Simple cation-exchange high-performance liquid chromatography optimized to the measurement of metabolites in the effluents from perfused rat livers using refractive index and ultraviolet detectors. J. Chromatogr., 563: $231-242$

Nettles, C. G. and S. F. Barefoot 1993 Biochemical and genetic characteristics of bacteriocins of foodassociated lactic acid bacteria. J. Food Prot., 56: 338-356

Nielsen, J. W., Dickson, J. S. and J. D Crouse 1990 Use of a bacteriocin produced by Pediococcus acidilactici to inhibit Listeria monocytogenes associated with fresh meat. Appl. Environ. Microbiol., 56: 2142-2145

Pucci, M. J., Vedamuthu, E. R., Kunka, B. S. and P. A. Vandenburgh 1988 Inhibition of Listeria monocytogenes by using bacteriocin PA-1 produced by Pediococcus acidilactici PAC 1.0. Appl. Environ. Microbiol., 54: 2349-2353

Schved, F., Lalazar, A., Henis, Y. and B. J. Juven 1993 Purification, partial characterization and plasmidlinkage of pediocin SJ-1, a bacteriocin produced by Pediococcus acidilactici. J. Appl. Bacteriol., 74 67-77

Tagg, J. R., Dalan, A. S. and L. W. Wannamaker 1976 Bacteriocins of gram-positive bacteria. Microbiol. Rev., 40: 722-756 